\title{
溶融塩化ベリリウムの分解電圧*
}

\section{The Decomposition Voltage of Fused Beryllium Chloride}

\author{
黒田正**, 松 本修** \\ Tadashi Kuroda, Osamu Matsumoto
}

\section{1 緒言}

塩化ベリリウムの溶融電解により金属ベリりウムを製 造する祭仙両極間仁作用させる電位を塩化べリりウムの 分解電圧以上にする必要がある. 分解電圧の測定法とし ては二極法,電池起電力測定法などがある.Yang らう和 よび Smirnov ら ${ }^{2)}$ は $\mathrm{Be}(s) \mid \mathrm{BeCl}_{2}(l), \mathrm{KCl}+\mathrm{LiCl}$ (共 晶) $(l) \mid \mathrm{Cl}_{2}(g)$ 電池の起電力を塩化べリリウム濃度 0.1 モル分率以下において則定し, Markov ら ${ }^{3)}$ は $\mathrm{Be}(s)$ $\left|\mathrm{BeCl}_{2}(l), \mathrm{NaCl}(l)\right| \mathrm{Cl}_{2}(g)$ 電池の 起電力を 測定してい る.しかしいずれも実際の電解操作におけるよりも塭化 ベリリウムの濃度が著しく低い，筆者らはY Yang ら と同様の電池を形成し，㙁化べリリウムの濃度を大にし て起電力を測定した。ついで得られた結果を熱的デー 夕4) から求めた理論分解電圧と比較し，測定値を用いて $\mathrm{BeCl}_{2}(l), \mathrm{KCl}+\mathrm{LiCl}$ (共晶)系の熱力学的考察を試みた。

\section{2 試料および装置}

\section{1 試 料}

㙁化ベリリウム：先に報告した方法泉により調製した ものを再蒝留して用いた。

塩化カりウム，熄化りチウム：市販特級品を再結晶し 使用前に溶融破砕した。

㙁素：市販ボンベづめのものを使用し，硫酸シリカ ゲルにより脱水した。

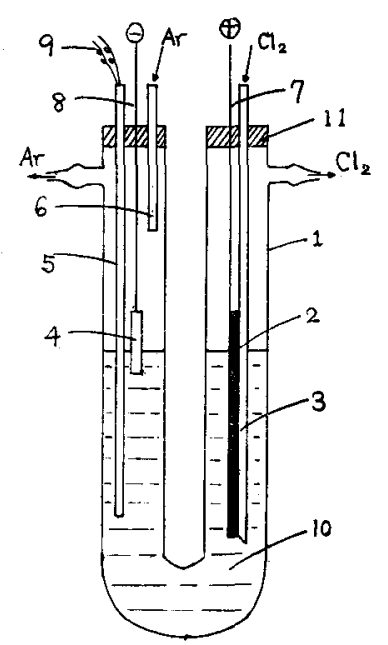

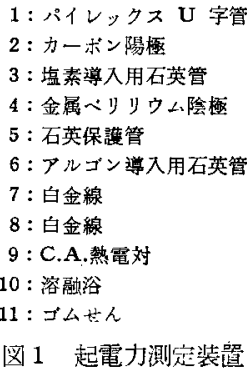

* 化学関低学協会連合秋季研究発䒾大会(昭和 37 年 10 月東京 $)$ 亿発表 **東京工業大学原子炤研究施設（東京都目黒区大岡山）

\section{2 蔆}

装置の概要を図 1 亿示す．容器はパイレックスガラス 管（径 $2 \mathrm{~cm}$ ）をU 字型にまげたもので陽極に分光分 析用カーボン（径 $6 \mathrm{~mm}$, 長さ $15 \mathrm{~cm}$ ), 㓌極にベリリウ 么金属捧（径 $5 \mathrm{~mm}$ ，長さ $1 \mathrm{~cm}$ ) を用い，そ机ぞれに白 金線を結びつけた。陽極には下部を $45^{\circ}$ に切った石英管

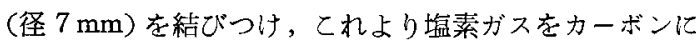
吹きつけるようにした。 また陰極上部にアルゴン導入用 の石英管をとりつけた．容器の加熱はニクロム線加熱電 気炉を用い；温度の測定は CA 熱電対を用いた，熱電 対の補正はスズ、アンチモンの凝固点を用いて行なっ た. 起電力の測定は村山電機製普通級電位差計 P-21 型 を，平衡点の検出は同社製 G21 型反照型検流計を用い た。

\section{3 測 定 方 法}

まず添加㙁を溶融させた後，アルゴンふんい気中で分 光分析用カーボン電極を用いて予備電解し，不純物の影 響を除いた後，塩化べリりウムの所定量を溶解させた． ついで陽極に塩素を吹きつけ約 30 分でカーボン表面に 塩素を飽和させた後，陽極ベリリウム金属を融体中に入 れて一定温度で起電力を測定した，一定の起電力をうる には約 10 分を要した。

\section{4 測 定 結 果}

塩化ベリリウムの融点は $399^{\circ} \mathrm{C}$, 沸点は $482^{\circ} \mathrm{C}$ 上報 告到されているので, $410 \sim 500^{\circ} \mathrm{C}$ 亿わたって塩化べリ リウム濃度 $0.2 \sim 0.6$ モル 分率の電池起電力を測定し, それぞれのモル分率 $\left(N_{1}\right)$ と電池起電力 $(E)$ を温度 (T) 亿対してとった結果を図 2 亿示す.

$E$ 之 $T$ は直線関係で $d E / d T$ は負で表 1 の実験式で 示される. $N_{1}=1.000$ 亿対する起電力は測定值の外そう によるものと熱的デーダにより次のように計算した結 果とをあわせて示した。

電池の起電反応を,

表 $1 \mathrm{Be}(s) \mid \mathrm{BeCl}_{2}(l), \mathrm{KCl}+\mathrm{LiCl}($ 共晶 $)(l) \mid \mathrm{Cl}_{2}(g)$ 電池の起電力

\begin{tabular}{|c|c|c|}
\hline$N_{1}(\mathrm{~mol}$ 分率 $)$ & $E_{T}=E_{410}-a(T-410)$ & 蔧 \\
\hline 0.188 & $E_{T}=2.165-8.1 \times 10^{-4}(T-410)$ & 実 测 佪 \\
\hline 0.410 & $E_{T}=2.103-8.7 \times 10^{-4}(T-410)$ & 実澌値 \\
\hline 0.613 & $E_{T}=2.045-9.2 \times 10^{-4}(T-410)$ & 実测㖽 \\
\hline 1.000 & $E_{T}=1.950-9.9 \times 10^{-4}(T-410)$ & 外关了值 \\
\hline 1.000 & $E_{T}=1.931-6.5 \times 10^{-4}(T-410)$ & 計算值 \\
\hline
\end{tabular}




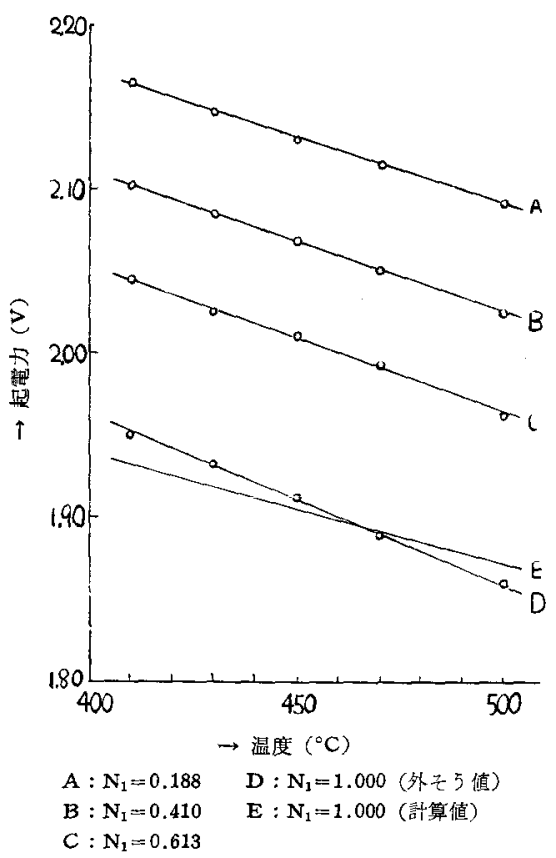

图 2 起電力と塩化ベリリウム濃度および温度との関係

$$
\mathrm{Be}(s)+\mathrm{Cl}_{2}(g)=\mathrm{BeCl}_{2}(l)
$$

上考光, 反応の自由エネルギー変化を $\Delta F$ とすると, 蛪 準電池起電力 $E^{\circ}$ 㹥,

$$
E^{\circ}=-\Delta F / 2 F_{r}
$$

で示される。たたし $F_{r}$ はフララ゙ー定数である。 $\Delta F$ を求めるために必要なデー夕を次に示す。

$\Delta C_{p}=5.2-1.5 \times 10^{-3} T+1.8 \times 10^{5} / T$

$\Delta H=5.2 T-0.75 \times 10^{-3} T^{2}-0.9 \times 10^{5} / T-113,317$

$\Delta S=11.98 \log T-1.5 \times 10^{-3} T-0.9 \times 10^{5} / T+63.7$

(3)〜(5)を用いて，

$$
\begin{aligned}
\Delta F= & -11.98 T \log T+0.75 \times 10^{-3} T^{2} \\
& -0.9 \times 10^{5} / T+68.9 T-113,317
\end{aligned}
$$

をうる。(6) と (2) 加ら $E^{\circ}$ が求められる。得られな結 果を表 2 に示与. 計算值と外そう値は $410^{\circ} \mathrm{C}$ で $15 \mathrm{mV}$, $500^{\circ} \mathrm{C}$ て $20 \mathrm{mV}$ 程度の差があるが, 熱的データの信頼 度からこの程度は許容されると考える。これ以後は $E^{\circ}$ として外そう值を用いるとととする。

表 2 熱的データによる起電力の計算值

\begin{tabular}{c|c|c|c}
\hline$T\left({ }^{\circ} \mathrm{C}\right)$ & $d F(\mathrm{kcal} / \mathrm{mol})$ & $E^{\circ}(\mathrm{V})$ & $d E / d T(\mathrm{~V} / \mathrm{deg})$ \\
\hline 410 & -89.10 & 1.931 & \\
450 & -88.88 & 1.905 & \\
500 & -86.35 & 1.872 & $-6.5 \times 10^{-4}$ \\
600 & $(-83.35)$ & $(1.805)$ & \\
700 & $(-80.40)$ & $(1.743)$ & \\
800 & $(-77.49)$ & $(1.680)$ & \\
\hline
\end{tabular}

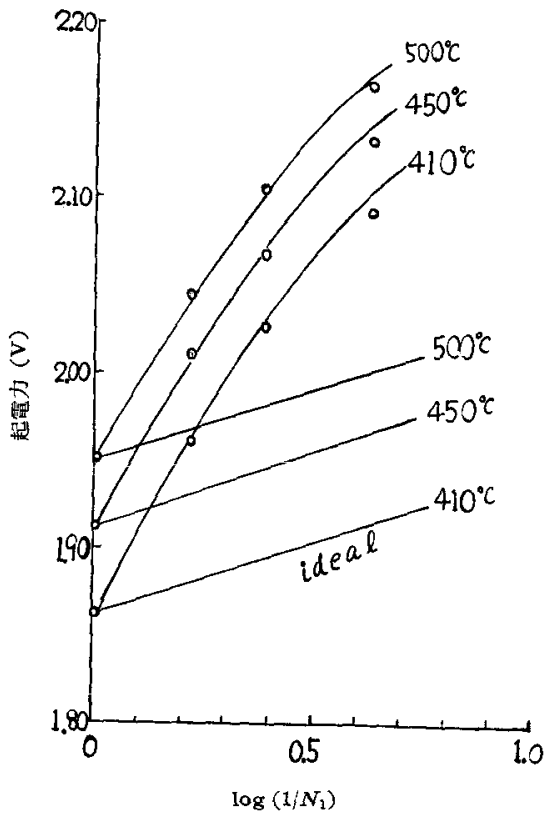

図 3 起電力と $\log \left(1 / N_{1}\right)$ 咸係

\section{5 考察}

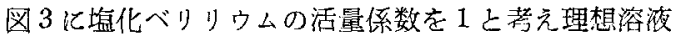
亿対する Nernst の式，

$$
E_{1}^{i}=E^{\circ}-\left(R T / 2 F_{r}\right) \cdot \ln N_{1}
$$

加方求めた起電力 $\left(E_{1}^{i}\right)$ と実測值の $\log \left(1 / N_{1}\right)$ 飞対 る関係を示す。

奏測された起雷力と理想溶液に対するそれとの間には 著しい差がみられ電池の起電反応は 2 電子反応であると はいい切れない，しかしながら熱的データによる計算值 と実測值の外そうにより求めた值が比较的よく一致して

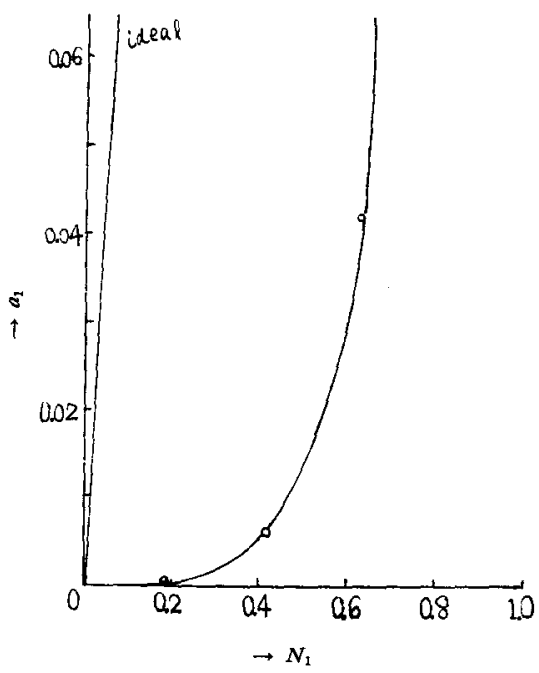

図4 塩化ベリリウムの濃度と活量の関係 $\left(410^{\circ} \mathrm{C}\right)$ 


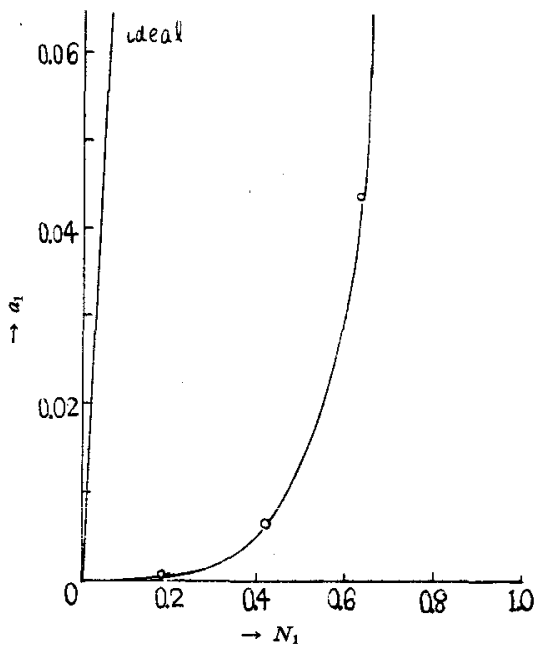

図 5 塭化ベリリウムの濃度と活量の関係 $\left(450^{\circ} \mathrm{C}\right)$

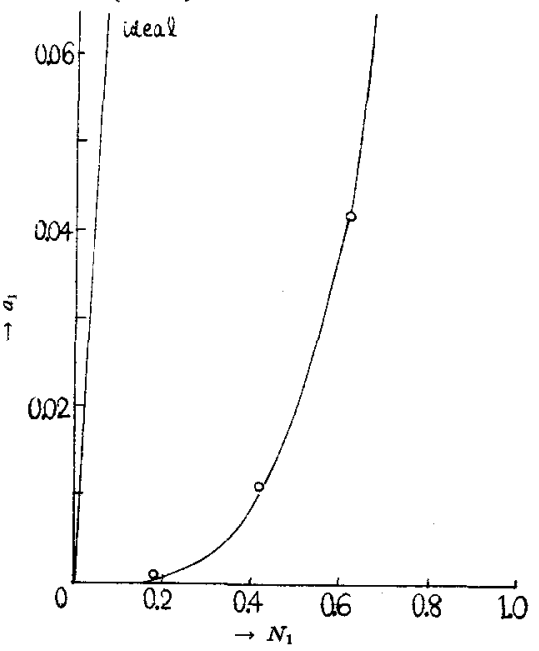

図 6 塩化ペリリウムの莀度と活量の関俰 $\left(500^{\circ} \mathrm{C}\right)$

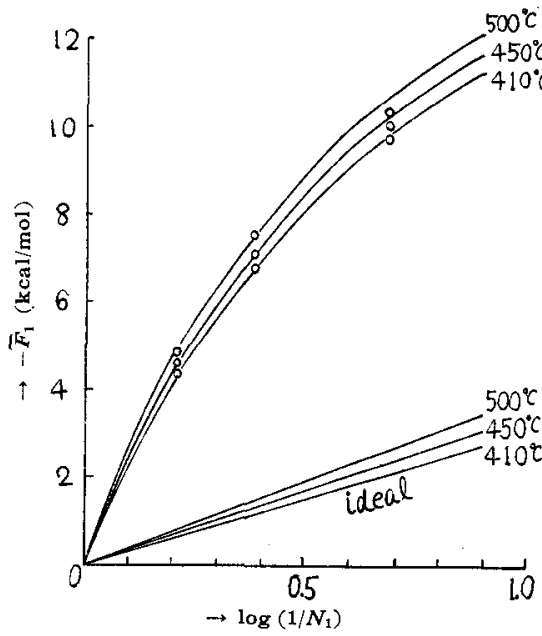

図7 $\log \left(1 / N_{1}\right)$ と $-\bar{F}_{1}$ との関係
表 3 溶融 $\mathrm{BeCl}_{2}, \mathrm{KCl}+\mathrm{LiCl}$ (共晶) 系の熱力学的性質 (1) $N_{1}=0.188$

\begin{tabular}{c|c|c|c|c|c|c|c|c}
\hline \hline$T$ & $E$ & $\begin{array}{c}\Delta F_{\mathrm{t}} \\
(\mathrm{cal} / \mathrm{mol})\end{array}$ & $\begin{array}{c}\bar{F}_{1} \\
(\mathrm{cal} / \mathrm{mol})\end{array}$ & $a_{1}$ & $f_{1}$ & $\begin{array}{c}d E / d T \\
(\mathrm{~V} / \mathrm{deg})\end{array}$ & $\left.\begin{array}{c}\Delta S_{1} \\
(\mathrm{cal} / \mathrm{deg} \\
\cdot \mathrm{mol}\end{array}\right)$ & $\left.\begin{array}{c}\bar{S}_{1} \\
(\mathrm{cal} / \mathrm{deg} \\
\cdot \mathrm{mol}\end{array}\right)$ \\
\hline 410 & 2.165 & $-99,876$ & $-9,847$ & $7.06 \times 10^{-4}$ & $3.7 \times 10^{-3}$ & & & \\
450 & 2.133 & $-98,400$ & $-10,219$ & $8.15 \times 10^{-4}$ & $4.3 \times 10^{-3}$ & $-8.1 \times 10^{-4}$ & -37.39 & 8.29 \\
500 & 2.092 & $-96,508$ & $-10,825$ & $8.69 \times 10^{-4}$ & $4.6 \times 10^{-3}$ & & & \\
\hline
\end{tabular}

$N_{1}=0.410$

\begin{tabular}{l|l|l|l|l|l|l|l|l}
\hline 410 & 2.103 & $-96,976$ & $-6,942$ & $6.01 \times 10^{-3}$ & $1.4 \times 10^{-2}$ & & & \\
450 & 2.068 & $-95,401$ & $-7,220$ & $6.56 \times 10^{-3}$ & $1.6 \times 10^{-2}$ & $-8.7 \times 10^{-4}$ & -40.13 & 5.53 \\
500 & 2.025 & $-93,417$ & $-7,635$ & $6.93 \times 10^{-3}$ & $1.7 \times 10^{-2}$ & & & \\
\hline
\end{tabular}

$N_{\mathrm{I}}=0.613$

\begin{tabular}{l|l|l|l|l|l|l|l|l}
\hline 410 & 2.045 & $-94,340$ & $-4,304$ & $4.19 \times 10^{-2}$ & $6.7 \times 10^{-2}$ & & & \\
450 & 2.010 & $-92,725$ & $-4,544$ & $4.24 \times 10^{-2}$ & $6.9 \times 10^{-2}$ & $-9.2 \times 10^{-4}$ & -42.44 & 3.22 \\
500 & 1.962 & $-90,487$ & $-4,704$ & $4.40 \times 10^{-2}$ & $7.2 \times 10^{-2}$ & & & \\
\hline
\end{tabular}

$N_{1}=1.000$

\begin{tabular}{l|l|l|l|l|l|l|l|l}
\hline 410 & 1.950 & $-90,034$ & 0 & 1 & 1 & & & \\
450 & 1.912 & $-88,181$ & 0 & 1 & 1 & $-9.9 \times 10^{-4}$ & -45.66 & 0 \\
500 & 1.860 & $-85,783$ & 0 & 1 & 1 & & & \\
\hline
\end{tabular}

表 4 溶融 $\mathrm{BeCl}_{2}, \mathrm{KCl}+\mathrm{LiCl}$ (共晶) 系の熱力学的性質 (2)

$$
N_{\mathrm{I}}=0.188
$$

\begin{tabular}{c|c|c|c|c|c|c}
\hline$T$ & $\begin{array}{c}\Delta H_{1} \\
\left({ }^{\circ} \mathrm{C}\right)\end{array}$ & $\begin{array}{c}\Delta H_{1}^{i} \\
(\mathrm{cal} / \mathrm{mol})\end{array}$ & $\begin{array}{c}\Delta H_{\mathrm{comp}} \\
(\mathrm{cal} / \mathrm{mol})\end{array}$ & $\begin{array}{c}\bar{F}_{1}^{i} \\
(\mathrm{cal} / \mathrm{mol})\end{array}$ & $\begin{array}{c}\Delta F_{\mathrm{comp}} \\
(\mathrm{cal} / \mathrm{mol})\end{array}$ & $w_{12}(\mathrm{kcal} / \mathrm{mol})$ \\
\hline 410 & $-125,413$ & $-119,424$ & $-5,990$ & $-2,206$ & $-7,641$ & $-11.6(-8.5 R T)$ \\
450 & $-125,452$ & $-119,303$ & $-6,146$ & $-2,346$ & $-7,871$ & $-11.9(-8.3 R T)$ \\
500 & $-125,404$ & $-119,038$ & $-6,366$ & $-2,461$ & $-8,164$ & $-12.3(-8.0 R T)$ \\
\hline
\end{tabular}

$N_{1}=0.410$

\begin{tabular}{l|l|l|l|l|l|l}
$\mathbf{4 1 0}$ & $-124,449$ & $-119,972$ & $-4,477$ & $-1,013$ & $-5,929$ & $-10.9(-12.4 R T)$ \\
$\mathbf{4 5 0}$ & $-124,435$ & $-119,409$ & $-5,026$ & $-1,223$ & $-5,997$ & $-17.1(-11.9 R T)$ \\
$\mathbf{5 0 0}$ & $-\mathbf{1 2 4 , 4 7 0}$ & $-119,079$ & $-5,391$ & $-1,221$ & $-6,414$ & $-18.3(-11.9 R T)$ \\
\hline
\end{tabular}

$N_{1}=0.613$

\begin{tabular}{l|l|l|l|l|l|l}
\hline 410 & $-123,328$ & $-119,239$ & $-4,087$ & -412 & $-3,894$ & $-25.9(-19.0 R T)$ \\
450 & $-123,419$ & $-119,213$ & $-4,206$ & -619 & $-3,925$ & $-26.2(-18.2 R T)$ \\
$\mathbf{5 0 0}$ & $-123,278$ & $-119,006$ & $-4,272$ & -773 & $-3,931$ & $-26.2(-17.0 R T)$ \\
\hline
\end{tabular}

$N_{\mathrm{t}}=1.000$

\begin{tabular}{l|l|l|l|l|l|l}
\hline 410 & $-121,291$ & $-121,291$ & 0 & 0 & 0 & 0 \\
450 & $-121,103$ & $-121,103$ & 0 & 0 & 0 & 0 \\
500 & $-121,065$ & $-121,065$ & 0 & 0 & 0 & 0 \\
\hline
\end{tabular}

いることから，電池の起電反応は $\mathrm{Be}(s)+\mathrm{Cl}_{2}(g)=\mathrm{BeCl}_{2}$ (g) という 2 電子反応であると考えられる。

起電力測定值と熱力学的反応との対応が示されたので 各組成に晾引る熱力学的特性值の算出を試み結果を表 3 およご表 4 亿示す.

表中 $E$ は電池起電力測定值， $\Delta F$ を塩化ベリリウム の生成自由エネルギー， $\bar{F}_{1}$ は希秎の自由エネルギー， $\Delta S_{1}$ はエントロピー変化， $\bar{S}_{1}$ は微分分子エントロピー， $a_{1}$ は活量, $f_{1}$ は活量係数を示す.

表 3 中の $a_{1}$ 亡 $N_{1}$ の関係を図 4 ，図 5 および図 6 に 示す. $a_{1}$ は著しく小の值をとり理想溶液のそれに比心 て著しく下方にトッの曲線を与える。 


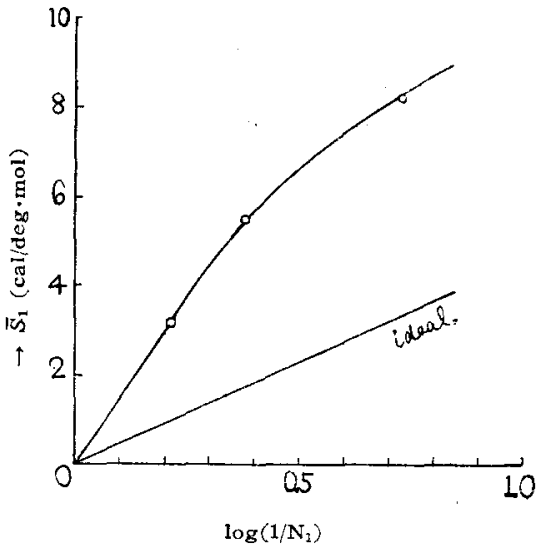

図8 $\bar{S}_{1}$ と $\log \left(1 / N_{1}\right)$ 関係

図7は $\bar{F}_{1}$ を $\log \left(1 / N_{1}\right)$ に対してとったもので実測 值仕 Raoult の法則から求められる理想溶液のそれに比 べて著しく負である。

图 8 は $\vec{S}_{1}$ を $\log \left(1 / N_{1}\right)$ に対してとった関係を示す。 実测值は理想溶液のそれに比べて著しく正に倨㥓してい る.

以上のような一連の関係俘より $\mathrm{BeCl}_{2}(l), \mathrm{KCl}+\mathrm{LiC}^{1}$ (共晶) (l) 系を理想溶液として取り扱うことは無理であ 引う.

表 3 中に示したごとく $f_{1}$ が小さいというととは融体 中においてなんらかの形で錯体の形成がなされているの ではないかということを示している。このことは溶液を 正則溶液と考光,

$$
f_{1}=\exp \left\{\left(w_{12} / R T\right) N_{2}^{2}\right\}
$$

より混合の土ネルギー，

$$
w_{12}=\left(R T / N_{2}^{2}\right) \ln f_{1}
$$

方真で $8 R T$ 19RT という大きな值をもっているとと からも予想される。 $w_{12}$ が焦で $f_{1} \ll 1$ であることは混合 によって溶液が安定化することを示している．本奏駼の 場合は $f_{1} \ll 1$ で錯体の生成定数が大であることから鍇 体の安定化がうかがえる、末た $w_{12}$ 㔔角で大きな值を とることから運動のエネルギーは無視できると若えられ る.

ついで，測定值から電池の起電反応に基づく反応熱 $\Delta H_{1}$ が計算される。Cの傎は塩化ベりりウムと共融混 台物の間の錯体の生成熱を含んでいる．塩化べリリウム の理想溶液にわける反灾熱主 $\Delta H_{\mathrm{i}}{ }^{i}$ とすると，

$$
\Delta H_{\text {comp }}=\Delta H_{1}-\Delta H_{1}{ }^{i}
$$

によって鍇体の生成熱 $\Delta H_{\text {comp }}$ が求妨られる。本実験 の場合 $\Delta H_{\mathrm{comp}}$ がー4〜 -6 kcal $/ \mathrm{mol}$ という值を示し， このとともまた錯体の生成を子想させる。

Wilkinson ら ${ }^{6)}$ は凝固点降下法てよって塭化ベリりウ ム之塩化ナトリウムの間に錯化合物 $\mathrm{NaBeCl}_{4}$ が存在す ることを見いだした。また Markov ら゙は $\mathrm{BeCl}_{2}-\mathrm{NaCl}$ (l) 系溶夜の安定化は, 錯体の生成によるものとしてい る.このととから $\mathrm{BeCl}_{2}(l), \mathrm{KCl}+\mathrm{LiCl}$ (共晶)(l) 系に おいても $\mathrm{K}_{2} \mathrm{BeCl}_{4}$ のような錯体の生成が予想される。

融体を理想溶液と若え Nernst の式において $f_{\mathrm{t}}=1$ と すれば，理想溶液に対する起電力 $E_{1}{ }^{i}$ は (7) に示すご とくである。実測されだ起電力 $E_{1}$ と $E_{1}{ }^{i}$ の差を $\Delta E$ : とすると，

$$
\begin{aligned}
& \Delta E=E_{1}-E_{1}^{i} \\
& =\left[E_{1}^{\circ}-\left(R T / 2 F_{r}\right) \cdot \ln a_{1}\right]-\left[E_{1}{ }^{\circ}-\left(R T / 2 F_{r}\right) \cdot \ln N_{1}\right] \\
& =-\left(R T / 2 F_{r}\right) \cdot \ln f_{1}
\end{aligned}
$$

となる、 $\Delta E$ が錯体生成のみに起因可るとすれば，錯体 生成の白由工市ルギー $\Delta F_{\text {comp }}$ は,

$$
\begin{aligned}
\Delta F_{\text {com } \mathrm{p}} & =-2 F_{r} \cdot \Delta E \\
& =R T \ln f_{1} \\
& =\bar{F}_{1}-\bar{F}_{1}{ }^{i} \\
& =w_{12} N_{2}{ }^{2}
\end{aligned}
$$

となる.表 4 亿示すように $\Delta F_{\text {comp }}$ は $-4 \sim-8 \mathrm{kcal} / \mathrm{mol}$ という值をとり，てのてとからも本実駼に扔けるような $f_{1} \ll 1$ の場含は，錯体の生成かその原因之洘えられる.

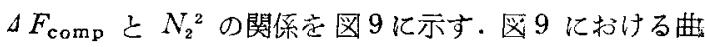
線関係は $\mathrm{BeCl}_{2}(l), \mathrm{KCl}+\mathrm{LiCl}$ (共晶) 系の正則溶液から のずれを示すと考えられる。

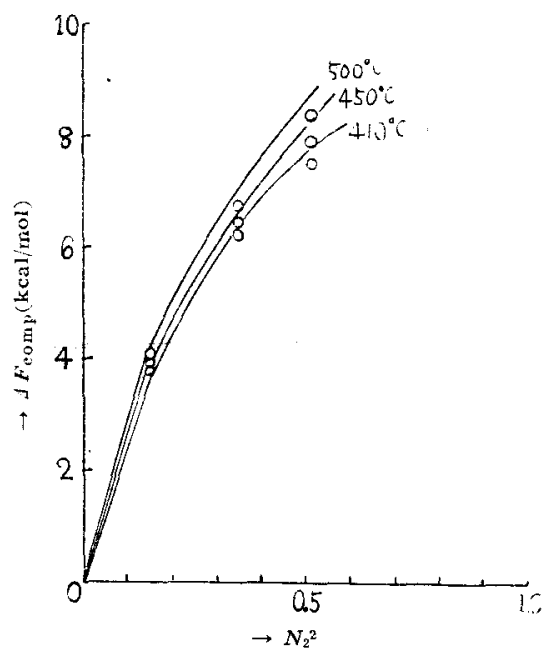

图 $9 \quad \bar{F}_{1}-\bar{F}_{1}{ }^{i}$ と $N_{2}^{2}$ 门関倸

\section{6 総 括}

(1) $\mathrm{Be}(s) \mid \mathrm{BeCl}_{2}(l), \mathrm{KCl}+\mathrm{LiCl}$ (共晶) (l) $\mid \mathrm{Cl}_{2}(g)$ の電池起電力を塩化べリりウム濃度 $0.2 \sim 0.6$ モル分率 の䈟团で，410 $500^{\circ} \mathrm{C}$ において測定し，起電力は温度 およご㙋化バリりウム濃度の関数であることを芫いだし ti.

（2）奏測值の堤化べリリウムのモル分率への外そう 值と熱的データを用いけ計算值がほぼ一致した。

(3) Nernst の式において $f_{1}=1$ こした場合の值と 
実測値との間には大きな差がみられた。とのととから電 池の起電反応は 2 電子反応であるとはいいきれないが， (2) のように外そう值と熱的データを用いた計算值の一 致から 起電反応は $\mathrm{Be}(s)+\mathrm{Cl}_{2}(g)=\mathrm{BeCl}_{2}(l)$ であると 推定した.

(4) 起電力の測定值加ら $\mathrm{BeCl}_{2}(l), \mathrm{KCl}+\mathrm{LiCl}$ (共 晶) (l) 系汇わ污る塩化べリリウムの熱力学的特性值を算 出し, Raoult の法則からの偏倚の原因を $\mathrm{K}_{2} \mathrm{BeCl}_{4}$ の上
うな゙錯体の生成によると考えた。

(昭 $38-4-2$ 受理)

$$
\text { 文献 }
$$

1) L. Yang, R.G. Hudson, Trans. AIME 215589 (1959).

2) M.V. Smirnov, N.Ya. Chukreev, Doklady Akad. Nauk. S.S.S.R. 127, 1066 (1959). C.A. 55, 25547 (1961).

3) B.F. Markov, Yu.K. Delimarsky, I.D. Pauchenko, Zhur. Fiz. Khim. 31, 2589 (1957).

4) A. Glassner, ANI-5750 (1957).

5) 黒田 正, 松本 修, 本詰 31，338 (1963)

6) E.Furby, K.L. Wilkinson, J. Inorg. \& Nuclear Chem. 14, $123(1960)$.

\section{水銀溢流式食塩電解 ソウの研究* \\ Studies on the Mercury Cell of Over-Flow Type Cathode}

沢田誠二**, 山本点**, 佐藤 正之草

Seiji SAWAda, Takashi Yamamoto, Masayuki Sato

\section{1 緒言}

筆者は先に水銀法食電解ソウにおいて高電流密度を可 能ならし引る条件を検討して,ソウ電圧てう配 $\beta=0.02$ $\mathrm{V} / \mathrm{Adm}^{-2}$ 以下を要することを知り,さらにてれを満すに は堅型電りウが望ましいことを知った。また陰極の長さ $L$ 之幅 $W$ につて $L / W$ が従来の常識的な值（6以 上）よりはなはな゙しく小さい値（たと光ば 0.2）でも実 用ソウとして可能であることわら, 別型式の電りウの構 想に達した，本報ではこの構想に基づく㹂型電ソウ開発 のための预储実験として，水銀溢流式垂直陰裋を有する $200 \mathrm{~A}$ および $3 \mathrm{kA}$ ソウについて報告する。

\section{2 水銀流下実験}

㹂型電りウには, 有名な岡田研究室の竪型回軽陰極り

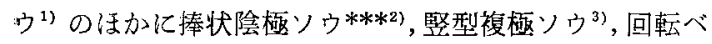
ルト型ソウ ${ }^{4)}$, 冈筒院極ソウ ${ }^{57}$, 特殊型陰極ソ .ヴ ${ }^{6}$, 日軽型 ソウ"), 舆羽 $V$ 型ソウ ${ }^{8)}$ が提案されており外国ではDe

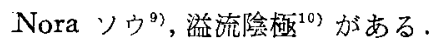

これらを大別すると陰極として金網または捧状陰極を 用いるものと鉄板を使用するすのとに分けられる。

筆者は陰極傾斜角度 $\theta$ を適当に選ぶために鉄板とし， 両面陰極に均等に水銀を流下させるために溢流方式とし $t^{11)}$.

使用した電りウを図 1 亿示すが C-1 型として区別す る.

電ソウケースは $100 \times 100$ の角型とし中央に幅 $80 \times$ 高さ $125 \times$ 厚さ 12 の垂直陰極を配㯰する．陰極頂部を 図 2 亿示寸. 水銀は管 $\mathrm{D}$ を上暑してみぞ $\mathrm{E}$ に入り，

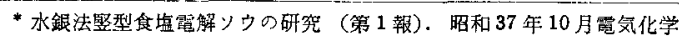
努会北陸支部大会汇七講演

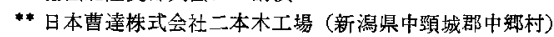

***区別のた筆者において適宜に付した名称（以下同様）
}
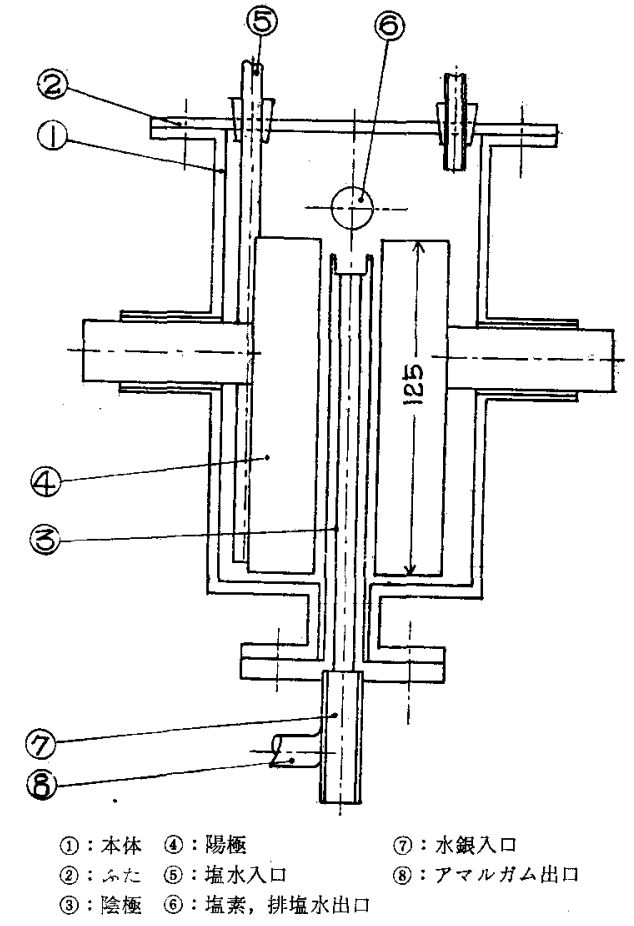

図 1 C-1 型電ソウ

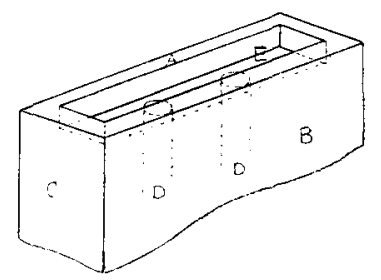

図 2 陰 極 頂 部

面 $\mathrm{A}$ から溢流して垂直面 $\mathrm{B}$ を流下し, 電りウ底部の 穴加ら図 1 , (8) 亿排出する。陰極画積を $80 \times 125 \times 2$ 面 